\title{
Effect of castration on plasma concentrations of luteinizing hormone and follicle-stimulating hormone in adult Merino rams which were homozygous carriers or non-carriers of the Booroola fecundity gene
}

\author{
C. A. Price*, N. L. Hudson and K. P. McNatty $\dagger$ \\ Wallaceville Animal Research Centre, Ministry of Agriculture \& Fisheries, Private Bag, \\ Upper Hutt, New Zealand
}

\begin{abstract}
Summary. Before castration, the mean plasma concentrations of luteinizing hormone (LH) and follicle-stimulating hormone (FSH) did not differ between $F F$ and ++ Booroola rams. After castration, mean $\mathrm{LH}$ and $\mathrm{FSH}$ concentrations increased after $8 \mathrm{~h}$, and for the next 14 days the rate of increase in FSH, but not $\mathrm{LH}$, secretion was significantly faster in $F F$ than in $++\operatorname{rams}(P<0.05)$. Mean FSH concentrations over this period were significantly higher in $F F$ than in ++ rams $(P<0.05)$. In both genotypes, the ranked FSH values did not significantly change their order over time, i.e. a significant within-ram effect was noted $(P<0.05)$. Repeated-measures analysis of variance indicated a significant effect of genotype on mean FSH secretion $(P<0.05)$ and a significant effect of sire in the $F F(P<0.05)$, but not the $++(P=0.76)$, genotype. From Day 28 to Day 58 after castration, FSH and LH concentrations were variable and no overall increases in concentrations were observed. The mean concentrations of both hormones over this period were not related to genotype.

There were no gene-specific differences in pulsatile LH secretion 14 weeks after castration. However, the mean LH, but not $\mathrm{FSH}$, response to a bolus injection of $25 \mu \mathrm{g}$ of gonadotrophin-releasing hormone (GnRH) was significantly higher in $F F$ than in $++\operatorname{rams}(P<0.05)$ and this was not significantly affected by sire.

These studies support the hypothesis that the $F$ gene is expressed in adult rams, in terms of pituitary responsiveness to an injection of GnRH and to the removal of the testes, but it is not clear from this study whether the influence of sire is related to or independent of the apparent gene-specific differences.
\end{abstract}

Keywords: Booroola; rams; LH; FSH; castration; fecundity

\section{Introduction}

The presence of the Booroola fecundity $(F)$ gene has various effects on the physiology and endocrinology of the pituitary-gonadal axis in sheep. In adult ewes, these include an increase in plasma concentrations of follicle-stimulating hormone (FSH), the maturation of ovarian follicles at smaller diameters and high ovulation rates (McNatty \& Henderson, 1987; Fry et al., 1988; McNatty et al., 1989). In adult males, evidence for the expression of the $F$ gene is less convincing. Luteinizing hormone $(\mathbf{L H})$ pulse frequency was higher in Booroola than in control Merino rams in one study (Martin et al., 1987), although this was not confirmed in a subsequent study comparing

\footnotetext{
*Present address: Centre de recherche en reproduction animale, Faculté de médecine vétérinaire, Université de Montréal, CP 5000, St-Hyacinthe, Québec, Canada J2S 7C6.

$\dagger$ Reprint requests.
} 
homozygous carrier $(F F)$ and noncarrier $(++)$ rams (Price et al., 1991). Conversely, Martin et al. (1987) reported no gene-associated differences in $\mathrm{LH}$ release after a challenge by gonadotrophinreleasing hormone (GnRH), whereas Price et al. (1991) reported significantly higher LH or FSH concentrations, depending on season, in $F F$ than in ++ rams after injection of GnRH. No data have yet shown a clear gene-specific difference in mean FSH concentrations (Bindon et al., 1985; Price et al., 1991).

Potential gene-related differences with regard to FSH secretion are difficult to detect in adult rams as plasma concentrations are lower than those in ewes, as measured under similar assay conditions (ewe: McNatty et al., 1987; Currie \& Rawlings, 1989; ram: Bindon et al., 1985; Price et al., 1991). One method of increasing FSH concentrations is the removal of both testes (Schanbacher, 1979, 1988; Caraty, 1983). This treatment also increases pulsatile LH secretion and the amount of LH released in response to an injection of GnRH (D'Occhio et al., 1982, 1983; Caraty \& Locatelli, 1988). One study comparing castrated rams reported no differences in mean LH or FSH secretion between Booroola and Merino strains, although the effects of castration on pulsatile and GnRH-stimulated LH secretion were not reported (Bindon et al., 1985).

The present study extended the above observations by examining the post-castration rise in mean LH and FSH concentrations, pulsatile LH secretion, and the LH response to a GnRH challenge in $F F$ and in ++ Merino rams. A preliminary report of these data has appeared elsewhere (Price et al., 1990).

\section{Materials and Methods}

Animals. The 2.5-year-old $F F(n=15)$ and $++(n=14)$ Booroola Merino rams used in this study were maintained outdoors at the Wallaceville Animal Research Centre (latitude $41^{\circ} \mathrm{S}$ ) and the study was approved by the Wallaceville Animal Ethics Committee. The mean ( \pm s.e.m.) body weights of these animals were significantly different between genotypes $(44.5 \pm 1.2$ and $49.3 \pm 1.2 \mathrm{~kg}$ for $F F$ and ++ , respectively; $P<0.01$ ), an effect attributed to differences in litter size (Price et al., 1991), but there was no difference in testis volume (107.1 $\pm 4 \cdot 8$ and $95 \cdot 8 \pm 9 \cdot 1 \mathrm{ml}$ for $F F$ and ++ respectively) measured in vivo (Price $e t$ al., 1991) 5 days before surgery. These animals were born as a result of controlled matings between $F F$ ewes and rams, or between ++ ewes and rams. These dams and sires had been assigned to their respective genotypes, according to the criteria of Davis et al. (1982), as a result of extensive pedigree and progeny testing. The $F F$ rams were derived from 13 ewes and 7 sires, and the ++ rams from 15 ewes and 3 sires.

Experiment 1. To monitor changes in gonadotrophin secretion before and after castration, blood samples were collected daily by jugular venepuncture, starting 12 days before castration. Two days before castration, each animal received a jugular cannula (using local anaesthesia and a minimum of restraint) and were blood sampled hourly from $24 \mathrm{~h}$ before to $36 \mathrm{~h}$ after castration. The daily blood samples were resumed 3 days after surgery, and continued until Day 14; thereafter, samples were collected 3 times a week until Day 58 after castration.

The castrations were performed in March (autumn in the Southern Hemisphere; 'active' testes, based on the classification of Lincoln, 1976). The testes were removed through a single incision high on the anterior surface of the scrotum. Anaesthesia was induced by thiopentone and maintained using halothane (Fluothane: Coopers Animal Health, Upper Hutt, New Zealand); sterile precautions were observed.

Experiment 2. To assess pulsatile LH secretion and the release of LH and FSH in response to GnRH, the animals were studied 14 weeks after castration when mean FSH and LH concentrations were assumed to have reached 'plateau' values. On the day following placement of a jugular cannula, blood samples were collected every 10 min for $12 \mathrm{~h}$. At the end of $12 \mathrm{~h}$, each animal received a single bolus injection of 0 (controls; $n=5 F F$ and $n=6++$ ), $0 \cdot 5$ $(n=4 F F$ and $n=5++)$ or $25 \mu \mathrm{g}(n=5 F F$ and $n=4++)$ GnRH (Peninsula Laboratories Inc, Belmont, CA, USA); blood sampling continued at 10 -min intervals for $2 \mathrm{~h}$ and then at 30 -min intervals for a further $6 \mathrm{~h}$.

Hormone assays. LH was measured by the radioimmunoassay (RIA) described by McNatty et al. (1987), using NIDDK-oLH-I-3 as tracer and NIAMDD-oLH-S23 as the reference preparation. All samples were assayed in duplicate. The minimum detectable concentration was $0.2 \mathrm{ng} / \mathrm{ml}$, and the intra- and interassay coefficients of variation were $\leqslant 4$ and $\leqslant 6 \%$, respectively.

FSH was assayed with a homologous RIA kit (McNatty et al., 1987) using NIAMDD-oFSH-I-1 as tracer, NIAMDD-oFSH-RP-1 as standard, and NIAMDD-anti oFSH-1 as antibody. The minimum detectable limit of this assay was $0.2 \mathrm{ng} / \mathrm{ml}$ and the intra- and interassay coefficients of variation were $\leqslant 4$ and $\leqslant 6 \%$, respectively.

Statistics. The postcastration increases in LH and FSH concentrations were analysed by linear regression, except when the data departed from linearity with time. In this case, a nonlinear, least-squares regression model (Wilkinson, 
1961) was used to compute maximum concentrations achieved during the sampling period ( $\left.V_{\max }\right)$ and the time to halfmaximal concentrations $\left(K_{\mathrm{m}}\right)$. This analysis is based on the assumptions that the overall castration response fits a rectangular hyperbole and that the source of the plasma hormone is not a limiting factor. Gene-specific differences in $V_{\max }$ and $K_{\mathrm{m}}$, and in plasma hormone concentrations within time points, were tested using analysis of variance, including sire as a main effect.

Partial autocorrelations were performed to establish the relative contribution of each ram to mean gonadotrophin concentrations over time. Where significant within-ram effects occurred, the data were further analysed by repeated measures analysis of variance, including sire, body weight and litter size as main effects.

The episodic LH data were examined using the methods of Van Look (1976) and Backstrom et al. (1982). An LH peak was defined as occurring when the hormone concentrations of two consecutive samples were greater than that of the mean of the two previous samples (basal samples) and the value of at least one of the peak samples exceeded the mean basal value by more than twice the coefficient of variation of the assay (which was set at $4 \%$ ). The amplitude of each peak was measured by subtracting the basal from the peak values, and the smoothed mean value was defined as the overall mean after all values on the peak had been removed.

\section{Results}

\section{Experiment 1.}

The mean LH and FSH concentrations over 12 days before castration were not different between genotypes (LH: $0.24 \pm 0.01$ and $0.27 \pm 0.02 \mathrm{ng} / \mathrm{ml}$; FSH: $0.21 \pm 0.02$ and $0.27 \pm 0.06 \mathrm{ng} / \mathrm{ml}$, for $F F$ and ++ , respectively; $P>0.05$ ).

The earliest increase in mean gonadotrophin concentrations was not evident until $8 \mathrm{~h}$ after surgery (Fig. 1). Thereafter, the increase in mean FSH concentrations was linear with time until $36 \mathrm{~h}(r=0.99 ; P<0.001)$ and the rate of rise of FSH was significantly higher in $F F$ than in ++ rams $(0.07 \pm 0.002$ and $0.04 \pm 0.001 \mathrm{ng} / \mathrm{ml} / \mathrm{h}$ respectively; $P<0.01 ;$ Fig. 1a). Analysis of variance indicated that this difference was caused by a significant within-ram effect $(P<0.05)$ rather than an effect of genotype. The increase in mean $\mathrm{LH}$ concentrations was linear with time until $16 \mathrm{~h}$ after castration $(r=0.96 ; P<0.001)$, after which a decrease in mean values was observed. The linear rate of increase of mean $\mathrm{LH}$ concentrations was not different between genotypes $(F F=0.16 \pm 0.02$ and $++=0.19 \pm 0.02 \mathrm{ng} / \mathrm{ml} / \mathrm{h} ; P>0.05 ; \mathrm{Fig} .1 \mathrm{~b}$ ). The mean (pooled genotype) increase in $\mathrm{LH}$ concentration with time was significantly faster than that of FSH $(0.17 \pm 0.01$ vs. $0.05 \pm 0.003 \mathrm{ng} /$ $\mathrm{ml} / \mathrm{h}$, for $\mathrm{LH}$ and $\mathrm{FSH}$, respectively; $P<0.001$ ) over $8-16 \mathrm{~h}$ after castration.

The pattern of daily gonadotrophin secretion from Day 3 to Day 58 following castration is shown in Fig. 2. The response of both hormones was linear with time until Day $14(r>0 \cdot 75$, $P<0.01$ ). The rate of rise of LH (Fig. 2b) over this period was not different between genotypes $(0.32 \pm 0.04$ and $0.21 \pm 0.07 \mathrm{ng} / \mathrm{ml} /$ day for $F F$ and ++ rams, respectively; $P>0.05)$ and there were no differences in mean $\mathrm{LH}$ concentrations over this period. The rate of increase in mean $\mathrm{LH}$ concentration over Days 3-12 was significantly slower than over $8-36 \mathrm{~h}$ after castration $(P<0.05)$.

Again in contrast to $\mathrm{LH}$, the increase in FSH concentrations from Day 3 to Day 12 was significantly faster in $F F$ than in ++ rams $(0.55 \pm 0.04$ and $0.29 \pm 0.03 \mathrm{ng} / \mathrm{ml} / \mathrm{day}$, respectively; $P<0.05$; Fig. 2a) and was significantly affected by sire $(P<0.05)$. The mean FSH concentrations over Days 3-12 were significantly higher in $F F$ than in $++\operatorname{rams}(7 \cdot 1 \pm 0.5$ and $4.9 \pm 0.7 \mathrm{ng} / \mathrm{ml}$ for $F F$ and ++ genotypes, respectively; $P<0.05$ ), and were not significantly affected by sire $(P>0.05)$. Autocorrelation analysis of mean FSH concentrations over time showed that there was a significant ram effect $(P<0.05)$, i.e. the rams with the highest FSH concentrations on one day were likely to have the highest values on subsequent days. Repeated-measures analysis of variance (Days 3-12) indicated a significant effect of sire on FSH concentrations within the $F F$ genotype $(P<0.05)$; this sire effect persisted when the data were tested for the 3 sires that had $\geqslant 3$ sons in this study and for the 5 sires with $\geqslant 2$ sons, but there was no significant sire effect within the ++ genotype ( $P=0.76$; all sires had 3 or more sons in the study). There was no effect of litter size or body weight on FSH secretion. As observed for LH, the rate of increase of FSH was significantly lower over Days 3-12 than over 8-16 h after castration $(P<0.05)$. 

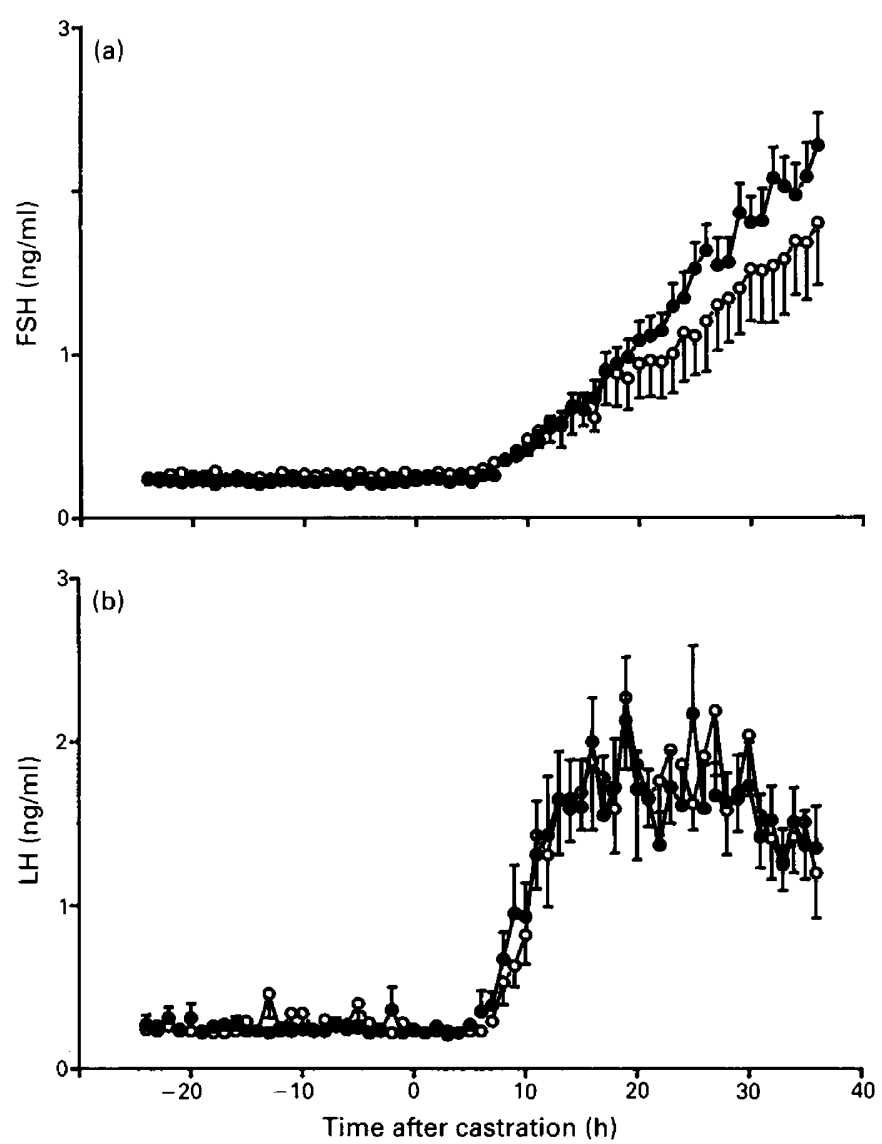

Fig. 1. Mean ( \pm s.e.m.) plasma concentrations of (a) follicle-stimulating hormone (FSH) and (b) luteinizing hormone (LH) in $F F(O ; n=15)$ and $++(O ; n=14)$ adult Merino rams from $24 \mathrm{~h}$ before to $36 \mathrm{~h}$ after castration.

From Day 28 to Day 58 after castration, FSH and particularly LH secretion were variable with time and there was no overall increase in mean concentrations. These mean 'plateau' concentrations were $4.3 \pm 0.5$ and $5.8 \pm 0.8 \mathrm{ng} \mathrm{LH} / \mathrm{ml}$ and $10.4 \pm 0.6$ and $9.4 \pm 0.8 \mathrm{ng} \mathrm{FSH} / \mathrm{ml}$ for $F F$ and ++ rams, respectively. No gene-specific differences were noted.

Nonlinear least-squares regression of all FSH data from Day 3 to Day 58 after castration indicated that the maximum concentrations reached were not different between genotypes $\left(V_{\max }=\right.$ $11.8 \pm 0.8$ and $12.8 \pm 1.3 \mathrm{ng} / \mathrm{ml}$ for $F F$ and ++ rams, respectively; $P>0.05$ ), but that the time to half-maximal concentrations was significantly shorter in $F F$ than in $++\operatorname{rams}\left(K_{\mathrm{m}}=4.9 \pm 0.9\right.$ and $14.9 \pm 3.6$ days for $F F$ and ++ , respectively; $P<0.05$ ). There was no significant effect of sire on $K_{\mathrm{m}}$ value.

\section{Experiment 2}

Values for the pulsatile secretion of LH 14 weeks after castration in $F F$ and ++ rams $(n=14$ / genotype; one $F F$ ram died prior to the start of Exp. 2) are given in Table 1. No gene-specific differences were noted.

There were no differences in mean gonadotrophin concentrations between groups before GnRH treatment, so the data were not transformed. Analysis of mean LH concentrations over $2 \mathrm{~h}$ after injection revealed a significant effect of GnRH dose $(P<0.001)$ and a significant gene $\times$ dose 

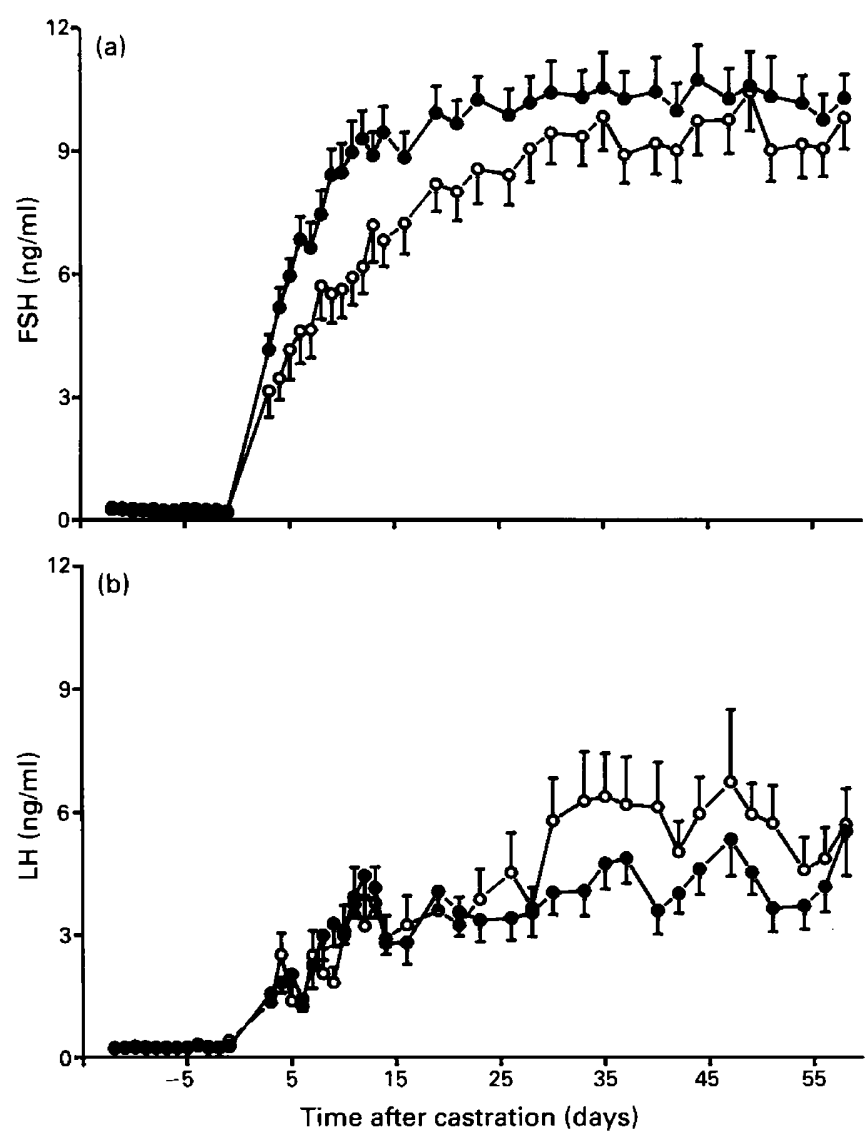

Fig. 2. Mean ( \pm s.e.m.) plasma concentrations of (a) follicle-stimulating hormone (FSH) and (b) luteinizing hormone (LH) in $F F(0 ; n=15)$ and $++(O ; n=14)$ adult Merino rams from 12 days before to 58 days after castration.

Table 1. Pulsatile secretion of luteinizing hormone 14 weeks after castration in $F F$ and ++ Booroola rams $(n=14 /$ genotype)

\begin{tabular}{lcccc}
\hline & $\begin{array}{c}\text { Overall } \\
\text { mean } \\
(\mathrm{ng} / \mathrm{ml})\end{array}$ & $\begin{array}{c}\text { Smoothed } \\
\text { mean } \\
(\mathrm{ng} / \mathrm{ml})\end{array}$ & $\begin{array}{c}\text { Pulse } \\
\text { amplitude } \\
(\mathrm{ng} / \mathrm{ml})\end{array}$ & $\begin{array}{c}\text { Pulse } \\
\text { frequency } \\
\text { (per 12 h) }\end{array}$ \\
\hline$F F$ & $5.6 \pm 0.7$ & $3.6 \pm 0.4$ & $2.3 \pm 0.4$ & $10.3 \pm 0.4$ \\
$f+$ & $5.7 \pm 0.8$ & $3.7 \pm 0.5$ & $2.3 \pm 0.4$ & $10.1 \pm 0.6$ \\
\hline
\end{tabular}

Values are means \pm s.e.m. There were no significant differences between genotypes.

interaction $(P<0.001)$. Student's $t$ test between genotypes within each dose group indicated that the mean $\mathrm{LH}$ response was significantly higher in $F F$ than in ++ rams injected with $25 \mu \mathrm{g} \mathrm{GnRH}$ $(22.1 \pm 4.2$ and $10.5 \pm 1.9 \mathrm{ng} / \mathrm{ml}$ for $F F$ and ++ rams, respectively; $P<0.05)$; Fig. 3 illustrates the $\mathrm{LH}$ responses of the two genotypes over time. There was no effect of sire on the mean $\mathrm{LH}$ 


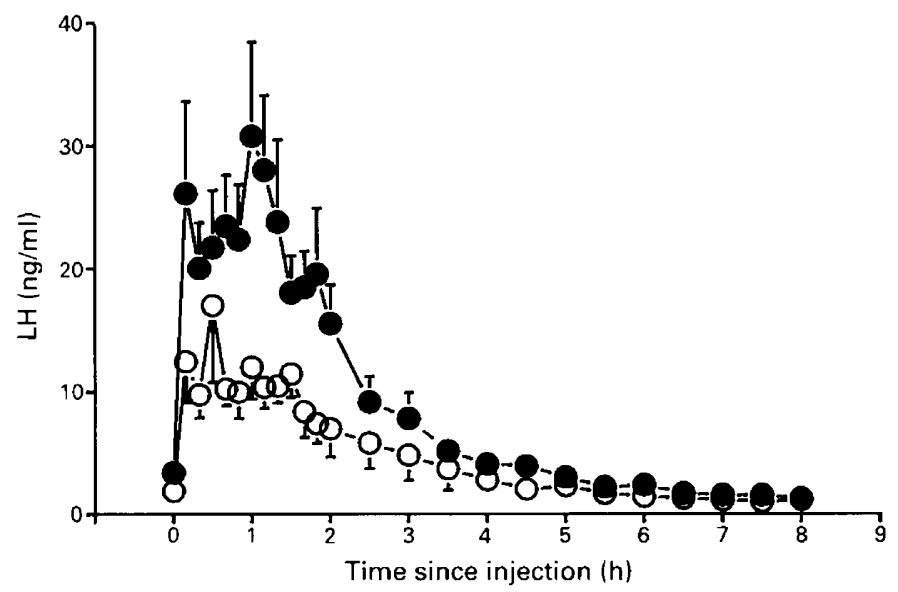

Fig. 3. Effect of a single bolus injection of $25 \mu \mathrm{g}$ gonadotrophin-releasing hormone on mean ( \pm s.e.m.) concentrations of luteinizing hormone $(\mathrm{LH})$ in $F F(\Theta)$ and $++(O ; n=14 /$ genotype) adult rams castrated 14 weeks previously.

response for either genotype $(P>0.05)$ and no effect of genotype for the 0 or $0.5 \mu \mathrm{g}$ GnRH dose groups.

There was no effect of GnRH on FSH secretion, irrespective of genotype.

\section{Discussion}

These studies have provided further evidence to support the hypothesis that the $F$ gene is expressed in adult Booroola rams. Specifically, the postcastration rise in FSH, but not LH, is significantly more rapid in $F F$ than in ++ rams, and pituitary responsiveness to exogenous $\mathrm{GnRH}$, with respect to $\mathrm{LH}$ release 14 weeks after castration, is also significantly higher in rams with the gene than in those without.

The evidence for a gene-specific effect on FSH secretion is as follows. Short-term blood sampling (hourly for $36 \mathrm{~h}$ after castration) revealed that the FSH responses of the two genotypes start to diverge $\sim 20 \mathrm{~h}$ after surgery and that the mean rate of rise of FSH in $F F$ rams was almost twice that in ++ rams. This relative difference was maintained in both direction and magnitude when measured in daily samples taken from 3 to 12 days after castration, but was lost once mean concentrations started to 'plateau', although the means never overlapped. Nonlinear regression analysis showed that maximum concentrations were not related to genotype and that the $F F$ rams reached half-maximal concentrations 3 times faster than the ++ rams. These latter data confirm that the apparent gene-specific difference is expressed in terms of the rate of the postcastration increase in FSH concentrations, and not the 'equilibrium' concentrations per se.

A previous report in the literature described the $\mathrm{LH}$ and FSH responses to castration in Booroola and control Merino rams over 8 days (Bindon et al., 1985). These data also indicated that the FSH, but not the $\mathrm{LH}$, response tended to be higher in $F$ gene carriers than in noncarriers, although these differences were not significant. The discrepancy between this and our present study may be caused by strain differences unrelated to the $F$ gene, potential misclassification of genotypes, different blood sampling frequency, or possible seasonal differences (time of year of castration was not reported by Bindon et al., 1985). A recent study in ewes reported that, whilst there were gene-specific differences in gonadotrophin secretion before ovariectomy and in 'plateau' concentrations after ovariectomy, the rates of increase in gonadotrophin concentrations were not different between genotypes (McNatty et al., 1989). Thus the hormone patterns in the present ram study are different 
from those in ewes. The reasons for this are unclear, as the experimental designs of the two trials were similar, the animals in both studies were of the same strain and were classified with respect to genotype by the same criteria. These data suggest that there may be a sexual dichotomy in the manner in which the $F$ gene is expressed with respect to pituitary function.

Differences in the concentrations of FSH may also reflect a change in the isoforms of FSH released. Robertson et al. (1984) have shown no differences in the forms of pituitary FSH between gonad-intact gene carrier and noncarrier rams. However, Keel \& Schanbacher (1987) showed that the electrophoretic profile of FSH changes after castration in rams and Fry et al. (1987) suggested that the half-life of FSH increases after ovariectomy in Merino ewes. These aspects warrant further study in Booroola rams.

The present results are confounded by the apparently high heritability of FSH secretion ( 0.63 in Merino ram lambs, cited by Bindon \& Piper, 1987). Partial autocorrelation analysis suggested that the highest FSH concentrations consistently occurred in the same individuals at different times. Moreover, a significant sire effect was noted with repeated-measures analysis of FSH concentrations and linear regression analysis on FSH over Days 3-12 after castration. A similar effect of sire has been reported in ram lambs (Seck et al., 1988; Purvis et al., 1989). However, the sire effect was evident within the $F F$ group, whereas such an effect was far from significant in the ++ group. By contrast, a gene-related difference was noted with respect to $\mathrm{LH}$ secretion after a GnRH challenge, which was not significantly affected by sire. This is consistent with our previous study (Price et al., 1991), in which LH release was twice as high in $F F$ as in ++ testes-intact rams after $\mathrm{GnRH}$ at the same time of the year, and which was also independent of sire. Collectively, these data suggest that the expression of the $F$ gene in rams with respect to FSH concentrations is closely linked to the sire effect, whereas the differences in $\mathrm{LH}$ secretion are gene-specific. The lack of a response of FSH concentrations to even $25 \mu \mathrm{g}$ GnRH implies that FSH secretion is maximal 3 months after castration, as has been previously observed (Bremner et al., 1980).

Since there are few reports of the acute gonadotrophin changes following castration in rams (Pelletier, 1968; Caraty, 1983; Bindon et al., 1985), the patterns of LH and FSH secretion in the present study, irrespective of genotype, are worthy of some comment. The short-term $\mathrm{LH}$ response was biphasic, with an initial increase starting $8 \mathrm{~h}$ after surgery, reaching a peak over $20-25 \mathrm{~h}$ and then declining $25-36 \mathrm{~h}$ after castration. A similar decline in LH secretion was noted at $48 \mathrm{~h}$ for the rams of Bindon et al. (1985). This differs from comparable data for ewes (McNatty et al., 1989) in which LH concentrations increased linearly with no evidence of a decrease $25-36 \mathrm{~h}$ after ovariectomy. This may reflect sex differences in the releasable pool of pituitary LH or in the pattern of GnRH pulsatility established after gonadectomy. By contrast, FSH exhibits a constant rise in the short term, consistent with the hypothesis that there is only one pool of pituitary FSH (Bremner et al., 1980). The difference in the timing of the initial rise of both gonadotrophins between ewes (3-4 h; McNatty et al., 1989) and in rams ( $8 \mathrm{~h}$; present study) may be caused by differences in the depth and/or duration of anaesthesia used for the surgery (Clarke \& Doughton, 1983). Another sex difference noticed is with respect to the rate of gonadotrophin increase; in the previous ewe study, FSH concentrations increased faster than those of $\mathrm{LH}$ during the first $15 \mathrm{~h}$ after ovariectomy, whereas in the present ram study the converse was observed. The longer-term (3-58 days) pattern of gonadotrophin secretion in the present study was similar to that reported for ewes (McNatty et al., 1989) and for cows (Schallenberger \& Peterson, 1982).

In summary, these data provide evidence to support the hypothesis that the $F$ gene is expressed in adult male sheep. In particular, the rate of increase in FSH concentrations is significantly faster in $F F$ than in ++ rams following castration, and $\mathrm{LH}$ release in response to exogenous GnRH is greater in $F$ carriers than in noncarriers. These results, with those in intact rams, suggest that the $F$ gene affects the sensitivity or responsiveness of the pituitary gland in the male.

We thank the staff of the Invermay Agricultural Research Centre for provision of the animals and details of their reproductive history. Special thanks to L. Shaw and L. Condell for the LH and 
FSH assays, to R. Bailey, A. Butler, M. Fisher, K. Henderson, D. Jensen, S. Lun, A. Pfeffer, P. Smith and D. Thurley for assistance with animal handling, blood sampling and surgery and to Dr L. M. Sanford (Macdonald College of McGill University, Montreal) for useful comments on an earlier draft of this paper. RIA reagents were obtained from the National Hormone \& Pituitary Program and the NIADDK. C. A. Price was a New Zealand NRAC Postdoctoral Fellow.

\section{References}

Backstrom, C.T., McNeilly, A.S., Leask, R.M. \& Baird, D.T. (1982) Pulsatile secretion of LH, FSH, prolactin, oestradiol and progesterone during the human menstrual cycle. Clin. Endocr. 17, 29-42.

Bindon, B.M. \& Piper, L.R. (1987) Physiological aspects of selection for increased reproductive rate. In Merino Improvement Programs in Australia, pp. 243-257. Ed. B. J. McGuirk. Australian Wool Corporation, Melbourne.

Bindon, B.M., Piper, L.R., Cummins, L.J., O'Shea, T., Hillard, M.A., Findlay, J.K. \& Robertson, D.M. (1985) Reproductive endocrinology of prolific sheep: studies of the Booroola Merino. In Genetics of Reproduction in Sheep, pp. 217-235. Eds R. B. Land \& D. W. Robinson. Butterworths, London.

Bremner, W.J., Findlay, J.K., Lee, V.W.K., de Kretser, D.M. \& Cumming, I.A. (1980) Feedback effects of the testis on pituitary responsiveness to luteinizing hormone-releasing hormone infusions in the ram. Endocrinology 106, 329-336.

Caraty, A. (1983) Ram hypothalamic-pituitary-gonadalinteractions. Effects of castration and cryptorchidism. Acta endocr. 102, 292-298.

Caraty, A. \& Locatelli, A. (1988) Effect of time after castration on secretion of LHRH and LH in the ram. J. Reprod. Fert. 82, 263-269.

Clarke, I.J. \& Doughton, B.W. (1983) Effect of various anaesthetics on resting plasma concentrations of luteinizing hormone, follicle-stimulating hormone and prolactin in ovariectomized ewes. J. Endocr. 98, $79-89$.

Currie, W.D. \& Rawlings, N.C. (1989) Fluctuation in responsiveness of $\mathbf{L H}$ and lack of responsiveness of FSH to prolonged infusion of morphine and naloxone in the ewe. J. Reprod. Fert. 86, 359-366.

Davis, G.H., Montgomery, G.W., Allison, A.J., Kelly, R.W. \& Bray, A.R. (1982) Segregation of a major gene influencing fecundity in progeny of the Booroola sheep in New Zealand. N.Z. J. agric. Res. 25, 515-529.

D'Occhio, M.J., Schanbacher, B.D. \& Kinder, J.E. (1982) Relationship between serum testosterone concentration and patterns of luteinizing hormone secretion in male sheep. Endocrinology 110, 1547-1554.

D'Occhio, M.J., Schanbacher, B.D. \& Kinder, J.E. (1983) Androgenic and oestrogenic steroid participation in feedback control of luteinizing hormone secretion in male sheep. Acta endocr. 102, 499-504.

Fry, R.C., Cahill, L.P., Cummins, J.T., Bindon, B.M., Piper, L.R. \& Clarke, I.J. (1987) The half-life of follicle-stimulating hormone in ovary-intact and ovariectomized Booroola and control Merino ewes. J. Reprod. Fert. 81, 611-615.

Fry, R.C., Clarke, I.J., Cummins, J.T., Bindon, B.M., Piper, L.R. \& Cahill, L.P. (1988) Induction of ovu- lation in chronically hypophysectomized Booroola ewes. J. Reprod. Fert. 82, 711-715.

Keel, B.A. \& Schanbacher, B.D. (1987) Charge microheterogeneity of ovine follicle-stimulating hormone in rams and steroid-treated wethers. Biol. Reprod. 37, 786-796.

Lincoln, G.A. (1976) Seasonal variation in the episodic secretion of luteinizing hormone and testosterone in the ram. J. Endocr. 69, 213-226.

Martin, G.B., Sutherland, S.R.D. \& Lindsay, D.R. (1987) Effects of nutritional supplements on testicular size and the secretion of $\mathrm{LH}$ and testosterone in Merino and Booroola rams. Anim. Reprod. Sci. 12, 267-281.

McNatty, K.P. \& Henderson, K.M. (1987) Gonadotrophins, fecundity genes and ovarian follicular function. J. Steroid Biochem. 27, 365-373.

McNatty, K.P., Hudson, N., Henderson, K.M., Gibb, M., Morrison, L., Ball, K. \& Smith, P. (1987) Differences in gonadotrophin concentrations and pituitary responsiveness to $\mathrm{GnRH}$ between Booroola ewes which were homozygous $(F F)$, heterozygous $(F+)$ and non-carriers $(++)$ of a major gene influencing their ovulation rate. J. Reprod. Fert. 80, 577-588.

McNatty, K.P., Fisher, M., Collins, F., Hudson, N.L., Heath, D.A., Ball, K. \& Henderson, K.M. (1989) Differences in the plasma concentrations of FSH and LH in ovariectomized Booroola $F F$ and ++ ewes. J. Reprod. Fert. 85, 705-713.

Pelletier, J. (1968) Elevation du taux de LH dans le plasma sanguin du bélier après castration. Ann. Biol. Anim. Biochem. Biophys. 8, 313-315.

Price, C.A., Hudson, N.L. \& McNatty, K.P. (1990) LH \& FSH after castration in adult rams with or without the Booroola F-gene. J. Reprod. Fert., Abstr. Ser. 5, abstr. 1.

Price, C.A., Hudson, N.L. \& McNatty, K.P. (1991) Plasma $\mathrm{LH}$ and FSH concentrations in adult rams which were homozygous carriers or non-carriers of the Booroola fecundity gene. J. Reprod. Fert. 91, 267-275

Purvis, I.W., Ford, J.R. \& Martin, G.B. (1989) Plasma FSH in Merino ram lambs with and without the Booroola $F$ gene. Proc. Aust. Soc. Reprod. Biol. 21, 10 (abstr).

Robertson, D.M., Ellis, S., Foulds, L.M., Findlay, J.K. \& Bindon, B.M. (1984) Pituitary gonadotrophins in Booroola and control Merino sheep. J. Reprod. Fert. 71, 189-197.

Schallenberger, E. \& Peterson, A.J. (1982) Effect of ovariectomy on tonic gonadotrophin secretion in cyclic and post-partum dairy cows. J. Reprod. Fert. $64,47-52$.

Schanbacher, B.D. (1979) The regulation of FSH secretion in rams. J. Reprod. Fert., Suppl. 26, 15-16. 
Schanbacher, B.D. (1988) Radioimmunoassay of inhibin: serum responses to unilateral and bilateral orchidectomy, Endocrinology 123, 2323-2330.

Seck, M., Hochereau-de-Reviers, M.-T. \& Boomarov, 0. (1988) Comparaisons des teneurs plasmatiques en hormone gonadotrope FSH, durant les trois premiers mois de la vie, chez des agneaux mâles, porteurs ou non du gène $" F\rangle$ de prolificité. C. r. hebd. Seance Acad. Sci., Paris 307, Série 3, 433-437.
Van Look, P.F.A. (1976) Studies on the pathophysiology of gynaecological endocrine disorders. Ph.D. thesis, University of Edinburgh.

Wilkinson, G.N. (1961) Statistical estimations in enzyme kinetics. Biochem. J. 80, 324-332.

Received 26 November 1990 